\title{
Long-term prognosis of haemangioblastoma of the CNS: Impact of von Hippel-Lindau disease
}

\section{Niemelä, M.}

1999

Niemelä , M , Lemeta , S , Summanen , P , Böhling , T , Sainio , M , Kere , J , Poussa , K, Sankila , R , Haapasalo , H , Kääriäinen , H , Pukkala , E \& Jääskeläinen , J 1999 , ' Long-term prognosis of haemangioblastoma of the CNS: Impact of von Hippel-Lindau disease ' , Acta Neurochirurgica , vol. 141 , pp. 1147-1156 . https://doi.org/10.1007/s007010050412

http://hdl.handle.net/10138/297730

https://doi.org/10.1007/s007010050412

publishedVersion

Downloaded from Helda, University of Helsinki institutional repository.

This is an electronic reprint of the original article.

This reprint may differ from the original in pagination and typographic detail.

Please cite the original version. 


\title{
Long-Term Prognosis of Haemangioblastoma of the CNS: Impact of von Hippel-Lindau Disease
}

\author{
M. Niemelä ${ }^{1}$, S. Lemeta ${ }^{2}$, P. Summanen ${ }^{3}$, T. Böhling ${ }^{4}$, M. Sainio ${ }^{5}$, J. Kere ${ }^{6}$, K. Poussa ${ }^{7}$, R. Sankila ${ }^{8}$, \\ H. Haapasalo ${ }^{9}$, H. Kääriäinen ${ }^{6}$, E. Pukkala ${ }^{10}$, and J. Jääskeläinen ${ }^{1}$ \\ ${ }^{1}$ Department of Neurosurgery, Helsinki University Hospital, Helsinki, Finland \\ ${ }^{2}$ Department of Neurology, Helsinki University Hospital, Helsinki, Finland \\ ${ }^{3}$ Department of Ophthalmology, Helsinki University Hospital, Helsinki, Finland \\ ${ }^{4}$ Department of Pathology, Helsinki University Hospital, Helsinki, Finland \\ ${ }^{5}$ Institute of Occupational Health, Helsinki, Finland \\ ${ }^{6}$ Department of Medical Genetics, Helsinki University Hospital, Helsinki, Finland \\ ${ }^{7}$ Department of Radiology, Helsinki University Hospital, Helsinki, Finland \\ ${ }^{8}$ International Agency for Research on Cancer, Lyon, France \\ ${ }^{9}$ Department of Pathology, Tampere University Hospital, Tampere, Finland \\ ${ }^{10}$ Finnish Cancer Registry, Helsinki, Finland
}

\section{Summary}

The aim was to assess the frequency of von Hippel-Lindau disease (VHL) and the long-term prognosis of VHL and non-VHL patients among 110 consecutive patients with haemangioblastoma (HB) of the CNS treated between 1953 and 1993 at one neurosurgical unit.

To reveal VHL manifestations we performed a detailed clinical and radiological examination (neuraxis and abdomen) (61/110), VHL-gene mutation analysis (40/110), and collection of all available clinical, imaging, operative and autopsy data from the hospitals involved. All patients were followed-up with a median of 14 years (excluding 14 operative deaths), and no patient was lost to follow-up. Altogether 49 patients died during the follow-up.

In the 14 VHL patients (13\%), HB(s) of the CNS were detected at a median age of 33 years, retinal $\mathrm{HB}(\mathrm{s})$ at 39 years, and renal cell carcinoma (RCC) at 43 years. The frequency of VHL in patients operated on for $\mathrm{HB}(\mathrm{s})$ was $29 \%$ before the age of 25 years, $19 \%$ between 25 and 45 years, and only $2 \%$ after 45 years. HB patients not meeting the VHL criteria had internal organ cysts in $14 \%$. One nonVHL patient (4\%) had two adjacent HBs in the same cyst wall. The growth rates of non-VHL and VHL-related HBs were similar as indicated by the median time to recurrence and the proliferation indices (MIB-1). Recurrence of the HB in patients whose primary operation was considered radical developed in four of the $10 \mathrm{VHL}$ patients at a median of 19 years, and in nine of the 74 non-VHL patients at a median of 11 years. The median length of life of all VHL and non-VHL patients was 46 and 63 years, respectively. In VHL, $\mathrm{RCC}$ and $\mathrm{HBs}$ were equal causes of death.

Keywords: Haemangioblastoma; von Hippel-Lindau disease; surgery; survival.

\section{Introduction}

Von Hippel-Lindau disease (VHL) is a rare (1/ 36000 live births) dominantly inherited cancer syndrome predisposing to multiple haemangioblastomas (HB) of the CNS and retina, renal cell carcinomas (RCC), pancreatic carcinoma, pheochromocytomas, and cysts in the kidneys, liver, and pancreas $[10,13,14$, $24,25,32,33,35,39,41,49,51]$. VHL is caused by a defect in the VHL tumour suppressor gene in chromosome 3p25-p26 [22]. The penetrance is high as almost $100 \%$ of carriers of a VHL gene defect will develop clinical manifestations by the age of 60 years [35], and so their children have a $50 \%$ risk of getting the disease. VHL clearly reduces the length of life as the mean age at death is 40 to 50 years [31]. Due to advances in microsurgery, RCC has exceeded HBs of the CNS as the leading cause of death in VHL [26].

The HB is a highly vascular, benign and wellcircumscribed, slowly growing solid or cystic neoplasm of the CNS and retina composed of stromal cells, endothelial cells, pericytes, and mast cells. The origin of the stromal cells, believed to be the true neoplastic cells of HB tissue, is still undefined [4]. HB may cause pol- 
ycythaemia by secreting erythropoietin from stromal or mast cells [3]. HB of the CNS is regarded to be sporadic in $60-90 \%$ of cases $[1,28,34,40]$ and then it is typically a single, cystic lesion of the cerebellum, brain stem or upper cervical medulla, presenting at the average age of somewhat over 40 years [27]. Multiple HBs are a typical manifestation of von Hippel-Lindau disease (VHL) in which HBs of the CNS occur about 10 years earlier than their sporadic counterparts [26, 41]. HB of the retina originates from the inner, midperipheral retina, and is histologically identical to $\mathrm{HB}$ of the CNS [16, 50, 51, 52]. Retinal HB is the first manifestation in about half of the VHL patients, and is usually bilateral and multifocal or becomes so over the years $[28,35,51]$. The mean age at presentation is 25 years $[21,28,31,35,52]$. There are sporadic retinal HBs without VHL [50], but their prevalence still remains undefined.

Long-term follow-up data of unselected HBs of the CNS treated with population responsibility are scarce. This study assessed the occurrence of VHL-associated manifestations, and the long-term outcome of VHL and non-VHL patients in a series of 110 patients with $\mathrm{HB}(\mathrm{s})$ of the CNS treated at one neurosurgical unit.

\section{Methods and Patients}

\section{Patients and Haemangioblastomas}

The files of the Department of Neurosurgery, Helsinki University Hospital, a unit with population responsibility, revealed 110 consecutive HB patients fulfilling the following criteria:

a. Primary operation for HB(s) of the CNS between 1953 and 1993 .

b. Histological verification of the solid part.

c. HB ascertained at histological re-examination by a neuropathologist (TB).

\section{Follow-up Data}

All available clinical data were collected to find out the occurrence of VHL manifestations in these $110 \mathrm{HB}$ patients $(50$ males, $60 \mathrm{fe}-$ males). The records of the Department of Neurosurgery and all other hospitals involved were surveyed for clinical, imaging, operative and autopsy evidence of VHL. The addresses and the death certificates of the patients were obtained from the Population Register Centre of Finland and the Statistics Finland. A detailed inquiry was sent to patients before the follow-up examination concerning all their illnesses, hospital admissions and operations. The follow-up time started at the date of the primary operation and ended at death (49 110 patients) or on August 31, 1998. No patient was lost to follow-up.

\section{Clinical Examination}

A detailed clinical examination to reveal signs of VHL was performed between 1991 and 1998 in 61 of the $66(92 \%)$ live patients. This included family history for VHL, a physical and neurological examination (MN), ophthalmological examination (PS) including indirect ophthalmoscopy and Goldmann 3-mirror contact lens fundus examination, enhanced MRI scan $(1.0 \mathrm{~T})$ of the head and upper cervical spine, and enhanced CT scan of the upper abdomen (kidneys, adrenals, liver and pancreas).

\section{Family Pedigrees and Finnish Cancer Registry}

Detailed pedigrees with first and second degree relatives were constructed for $35 \mathrm{HB}$ patients with at least some data suggestive of VHL, using the files of the Population Register Centre and the parish records. These 35 patients with their 471 relatives were linked with the files of the Finnish Cancer Registry (FCR) to find VHL related neoplasms (HB of the CNS, RCC, pancreatic carcinoma, pheochromocytoma). The population-based nationwide FCR has functioned since 1953. All hospitals, health care centers, physicians, and pathological laboratories are requested to notify FCR of all cancer cases (benign and malignant CNS tumours included) that come to their attention, and FCR also receives information of all death certificates with a cancer diagnosis: over $99 \%$ of the 63722 solid tumours diagnosed in Finland between 1985 to 1988 were recorded at FCR [47]. Furthermore, everybody living in Finland has had a 11digit personal identification code since 1967 allowing complete follow-up of every person for death and emigration, and also linking of registry data.

\section{Mutation Analysis}

Germ-line mutations of the VHL gene were analysed by direct sequencing from all live patients with clinically clear VHL [4], suspect patients with $\mathrm{HB}$ and internal organ cyst(s) [11], and also in 25 apparently sporadic HB patients (Table 1). High molecular weight DNA was extracted from peripheral blood leucocytes by the QiA Amp Blood kit (QiAGEN Ltd., Cambridge, UK). The three exons of the VHL gene (coding region of 852 nucleotides) were sequenced, including the exon splice sites. The primers and the PCR conditions (with slight modification) were as described elsewhere [7]. We also used a reverse primer for the exon 1, SS1, 5'GCGGTAGAGGGGCTTCAGACCGTG-3'. PCR products were purified with the QiA quick PCR purification kit (Qiagen, Hilden, Germany), and the sequencing reactions were done using the ABI PRISM DYE Terminator sequencing kit (Perkin-Elmer Applied Biosystems Division, Foster City, CA), and were analysed on the ABI 373 A sequencer. Both strands were sequenced.

\section{VHL Criteria}

Clinically, a patient with multiple HBs of the CNS with or without family history of VHL, or a patient having $\mathrm{HB}(\mathrm{s})$ of the CNS together with one of the following lesions was considered as having VHL: HB of the CNS, RCC, pancreatic carcinoma or pheochromocytoma $[9,28,30,31]$.

\section{Proliferation Potential}

Proliferation by MIB-1 (Ki-67) labelling could be studied in 39 of the primary $87 \mathrm{HBs}$ operated on between 1968 and 1993, and in 11 recurrences and second tumours of these patients. Briefly, monoclonal antibody MIB-1 (IgG, Immunotech, Marseille, France) was used on deparaffinised and rehydrated tissue sections. Sections were treated in a microwave oven and the primary antibody was visualized with a streptavidin-biotin technique (Zymed Laboratories, CA) [42]. Proliferation index (MIB-1 index) is the percentage of im- 
Table 1. Characteristics of 14 VHL and 96 Non-VHL Patients Operated on for HB(s) of the CNS (Median Values Given)

\begin{tabular}{|c|c|c|c|c|c|}
\hline & & VHL patients & $\begin{array}{l}\text { Patients with } \\
\text { visceral cysts }\end{array}$ & $\begin{array}{l}\text { Sporadic } \\
\text { patients }\end{array}$ & $\mathrm{p}$-value and test \\
\hline Number of patients & & 14 & 13 & 83 & \\
\hline $\operatorname{Sex} M / F$ & & $5 / 9$ & $7 / 6$ & $38 / 45$ & \\
\hline Retinal HBs & & $8 / 14$ & 0 & 0 & \\
\hline $\mathrm{RCC}$ & & $10 / 14$ & 0 & 0 & \\
\hline Visceral cysts & & $8 / 14$ & $13 / 13$ & 0 & \\
\hline \multicolumn{6}{|l|}{ First removal of $H B$} \\
\hline Age at surgery (years, range) & & $33(18-50)$ & $56(26-69)$ & $45(16-79)$ & 0.005 Kruskal-Wallis \\
\hline \multirow{2}{*}{$\begin{array}{l}\text { Pre-operative serum haemoglobin } \\
\text { in } \mathrm{g} / \mathrm{l} \text { (range) }\end{array}$} & males & $154(146-166)$ & $163(158-181)$ & $158(120-192)$ & \\
\hline & females & $136(121-161)$ & $150(130-159)$ & $140(118-191)$ & \\
\hline \multicolumn{6}{|l|}{ Site } \\
\hline Cerebellum & & $10(71 \%)$ & $11(85 \%)$ & $73(86 \%)$ & \\
\hline Brain stem & & 3 & 1 & 3 & \\
\hline Spinal & & 0 & 1 & 4 & \\
\hline Supratentorial & & 1 & 0 & 3 & \\
\hline Adjoining cyst & & $9 / 14(64 \%)$ & $9 / 13(69 \%)$ & $60 / 83(72 \%)$ & \\
\hline $\begin{array}{l}\text { Diameter of the solid part in } \mathrm{mm} \\
\text { (range) }\end{array}$ & & $22(10-46) n=8$ & $23(6-39) n=11$ & $20(4-45) n=38$ & \\
\hline \multicolumn{6}{|l|}{ Extent of removal } \\
\hline Complete & & $10(71 \%)$ & $12(92 \%)$ & $74(89 \%)$ & \\
\hline Partial & & 4 & 0 & 5 & \\
\hline Biopsy & & 0 & 1 & 4 & \\
\hline Operative deaths ( $<3$ months) & & 0 & 1 & 13 & \\
\hline \multicolumn{6}{|l|}{ Long-term follow-up (>2 years) } \\
\hline Number of patients & & 12 & 12 & 64 & \\
\hline Recurrence after complete removal & & $4 / 10$ & $0 / 11$ & $9 / 59$ & \\
\hline Time to recurrence in years (range) & & $19(2-25)$ & & $11(3-35)$ & 0.88 Mann-Whitney \\
\hline MIB-1 of available HBs & & $0.3 \%(\mathrm{n}=9)$ & $0.2 \%(\mathrm{n}=4)$ & $0.2 \%(\mathrm{n}=37)$ & \\
\hline Follow-up time in years (range) & & $16(4-26)$ & $13(4-25)$ & $16(2-36)$ & \\
\hline Death & & $11 / 12$ & $1 / 12$ & $18 / 64$ & \\
\hline \multirow[t]{2}{*}{ Age at death in years (range) } & HB & $47(46-51) n=3$ & & $66(55-81) n=6$ & 0.02 Mann-Whitney \\
\hline & $\mathrm{RCC}$ & $49(26-66) n=5$ & & & \\
\hline
\end{tabular}

munopositive tumour cell nuclei among at least 500 neoplastic nuclei [17].

\section{Statistical Methods}

Median and range were used to describe distributions, and the Mann-Whitney or Kruskal-Wallis tests to compare groups.

\section{Results}

\section{Distinction of VHL and Non-VHL Patients}

All available clinical data gathered during the median follow-up time of 14 years (range $0.3-36$ years) together with a detailed clinical examination (61/110 patients), family history (93/110 patients), detailed pedigree (35/110 patients), mutation analysis (40/110 patients) and linkage to the files of FCR (35 HB patients and 471 relatives) led to the distinction of three different patient groups: (a) 14 VHL patients; (b) 13 patients with a single $\mathrm{HB}$ and visceral cyst(s) but no other VHL manifestations; and (c) 93 apparently sporadic $\mathrm{HB}$ patients (Table 1). The linkage of $\mathrm{HB}$ patients and their relatives to the FCR files to find out VHL-related tumours did not disclose new families. The mutation analysis could be performed in 4 VHL patients, in 11 patients with a single $\mathrm{HB}$ and visceral cyst(s), and in 25 patients with a sporadic HB. The analysis revealed a missense mutation in two of the four VHL patients studied, but in none of the other 36 patients.

Exclusion of VHL was less certain in the 14 patients who died within three months after the primary operation, mostly in the early years. The median age at surgery was 55 years (range 24-68 years). According to the clinical data, all 14 were considered to be free of VHL. Only one of the deaths occurred during the last 10 years $(1 / 26)$ after a partial removal of a brain stem HB. 


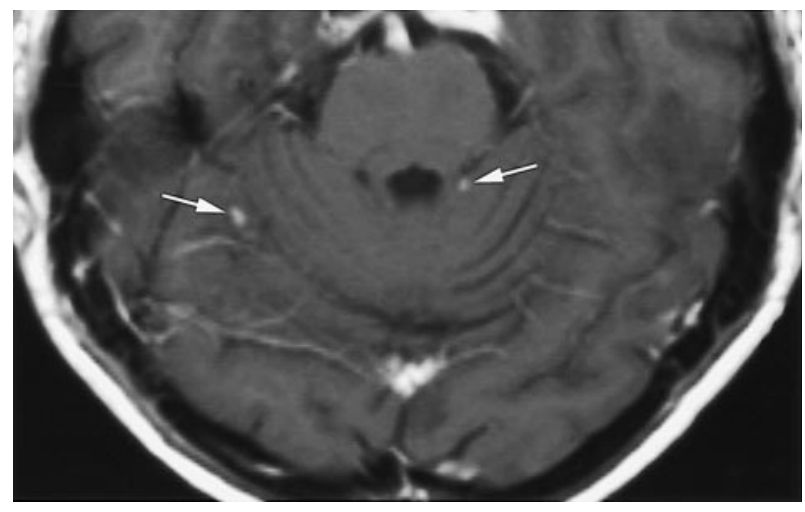

Fig. 1. MRI scan of two small solid cerebellar HBs (arrows) in a 52year-old VHL patient

\section{Characteristics of VHL Patients}

Of the unrelated 14 VHL patients (five males, nine females), six (43\%) had family history of VHL, and eight apparently had a new mutation. The frequency of VHL in patients operated on for $\mathrm{HB}(\mathrm{s})$ of the CNS was $31 \%(4 / 13)$ before the age of $25,19 \%$ (9/48) between 25 and 45 years, and only $2 \%(1 / 49)$ after 45 years. In 11 of the $14 \mathrm{VHL}$ patients $(79 \%), \mathrm{HB}(\mathrm{s})$ of the CNS was the first manifestation of the disease. Multiple HBs of the CNS were detected in 10 patients (Fig. 1) and a single one in four, retinal $\mathrm{HBs}$ in eight patients (5/8 bilateral), RCC in 10 patients (6/10 bilateral) (Fig. 2 ), and pheochromocytoma in two patients (one bilateral), pancreatic carcinoma in one patient, bilateral renal cysts in eight patients, and pancreatic cysts in three patients. No liver cysts were encountered. In the 14 VHL patients, the median age at the first operation for $\mathrm{HB}(\mathrm{s})$ of the CNS was 33 (18-50) years, significantly $(p=0.005)$ less than the $45(16-79)$ years in the 96 non-VHL patients (45 males, 51 females). The median age at the detection of retinal $\mathrm{HB}(\mathrm{s})$ was 39 (19-65) years. RCC was detected in 10 VHL (67\%) patients (two at autopsy) at a median age of 43 (26-57) years, and at a median interval of $11(0.1-25)$ years from the first operation for $\mathrm{HB}(\mathrm{s})$.

\section{$H B$ of the CNS}

The site of the HB(s) differed between VHL and non-VHL patients (Fig. 3): half of the 14 VHL patients had brainstem (Fig. 4) or spinal (Figs. 5 and 6) HB(s) at some stage, and only 5\% (5/96) and 4\% (4/96) of the non-VHL patients had a single HB in either of these two locations. Two of the 14 (14\%) VHL patients and
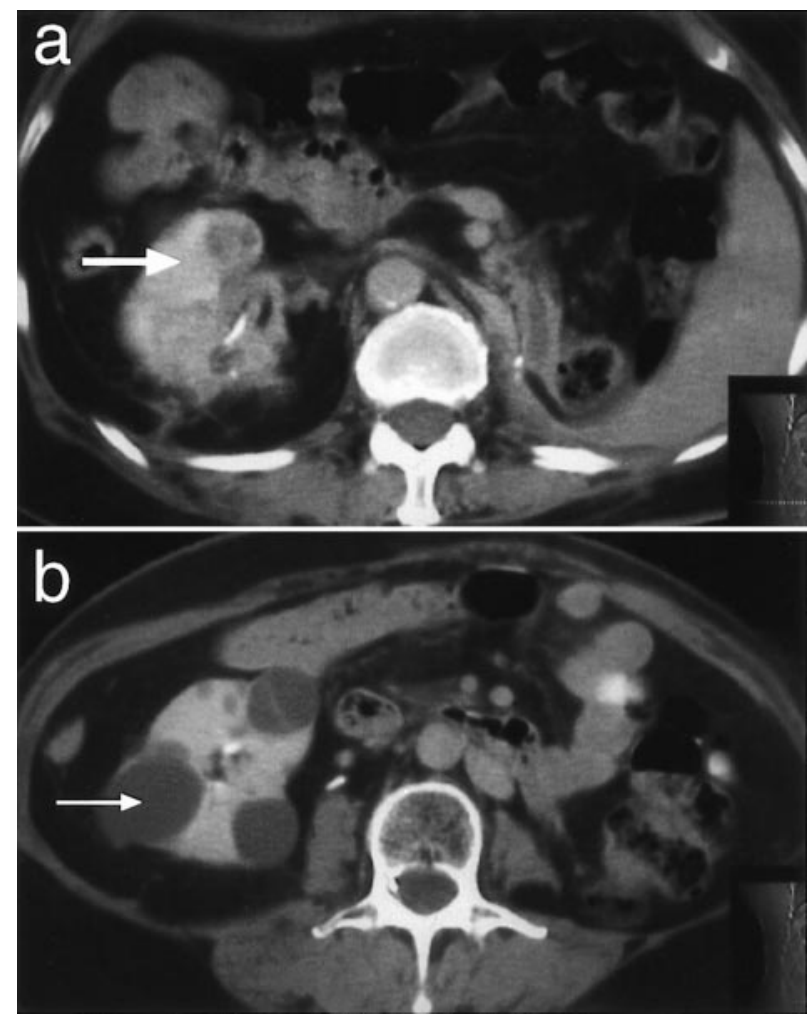

Fig. 2. Abdominal CT scan of a 64-year-old VHL patient with the right kidney removed because of RCC. In the left kidney there are RCC (a) and cysts (b)

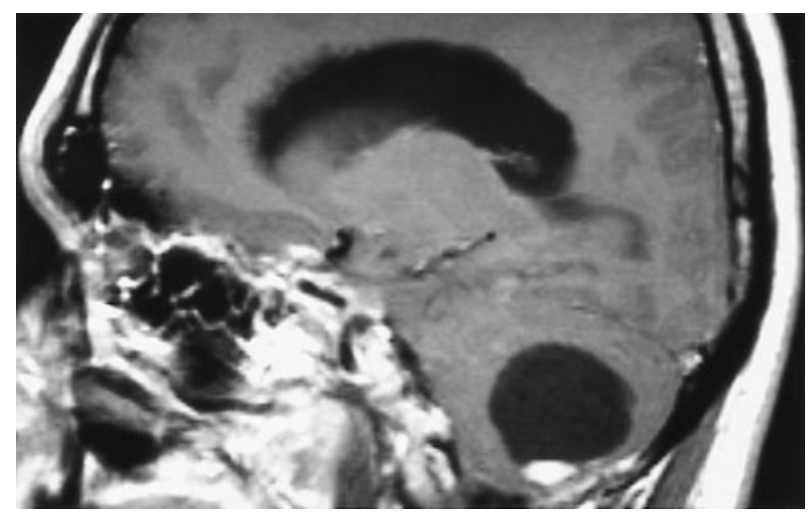

Fig. 3. MRI scan of a typical cystic cerebellar HB in a 39-year-old non-VHL patient

three of the $96(3 \%)$ non-VHL patients had a supratentorial HB. One patient had two adjacent HBs in the same cyst wall removed at the age of 38 years. However, negative family history, the lack of other VHL manifestations by the age of 58 years, and no germ-line mutation of the VHL gene together suggest that the adjacent HBs were not VHL-associated. Recurrence of an $\mathrm{HB}$ in the original operation area developed in four 


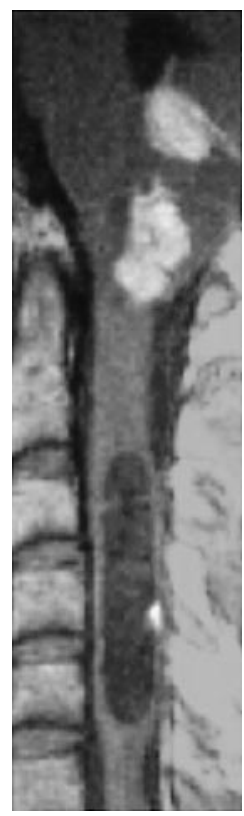

Fig. 4. Two solid brain stem HBs and a cystic $\mathrm{HB}$ in the cervical spine in a 32-year-old VHL patient
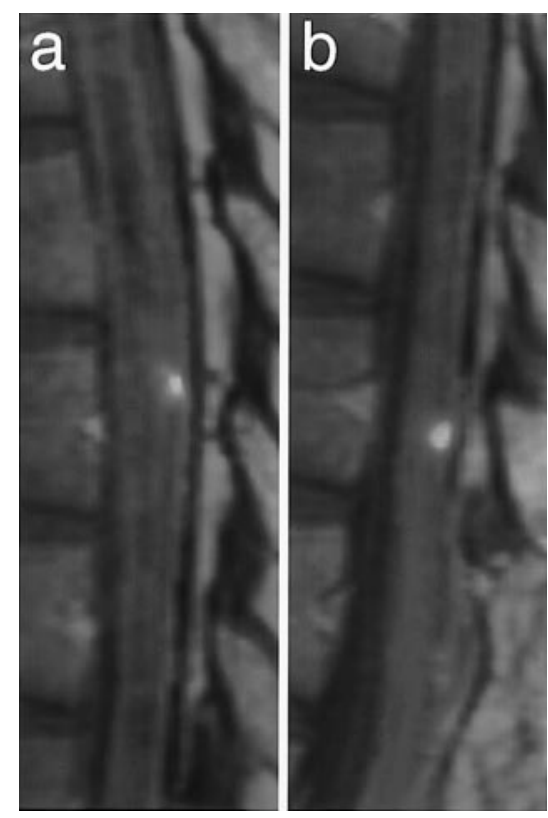

Fig. 6. Two small spinal HBs in the thoracic region ( $a$ and b) in the same patient as in Figure 5 three years later

\section{$H B$ of the Retina}

We performed a detailed ophthalmological examination of 60 of the 110 patients, and another 35 patients had had ophthalmoscopy earlier during the follow-up. No ophthalmological data was available for 15 patients. Retinal HBs (Fig. 8) were detected in (eight patients, and two of them had retinal HBs
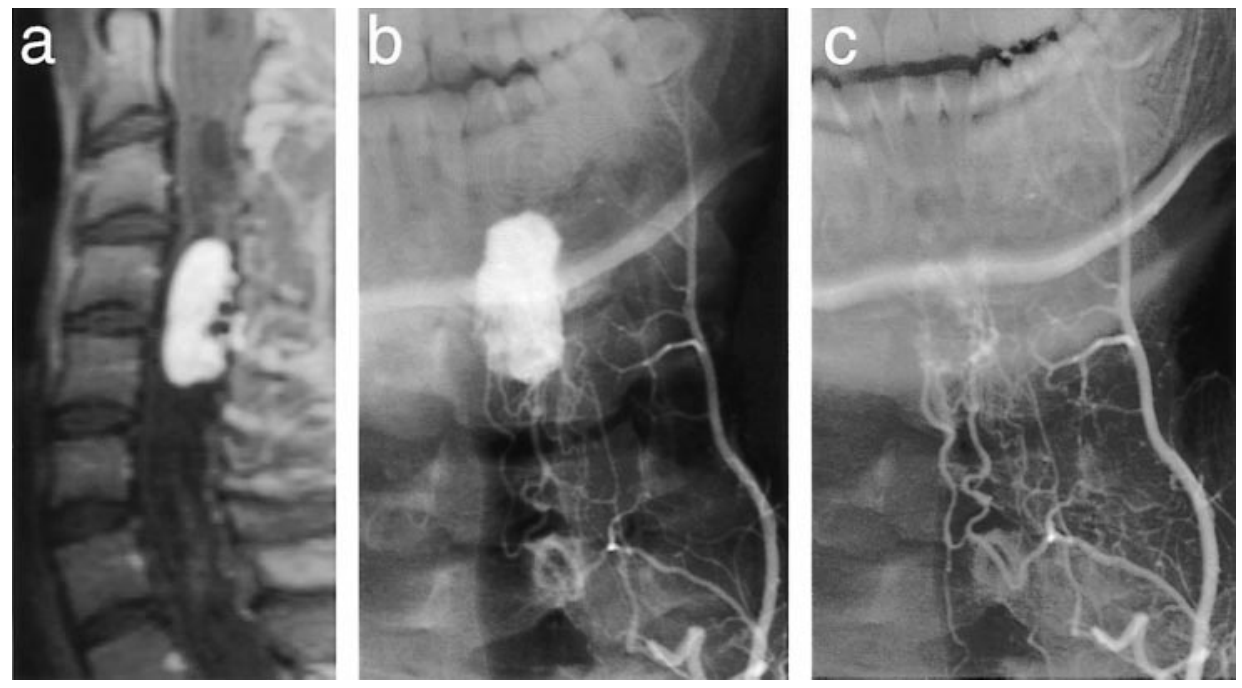

Fig. 5. An HB in cervical spine in a 21 year-old VHL patient: MRI with contrast (a), superselective angiography before (b) and after (c) preoperative embolization 


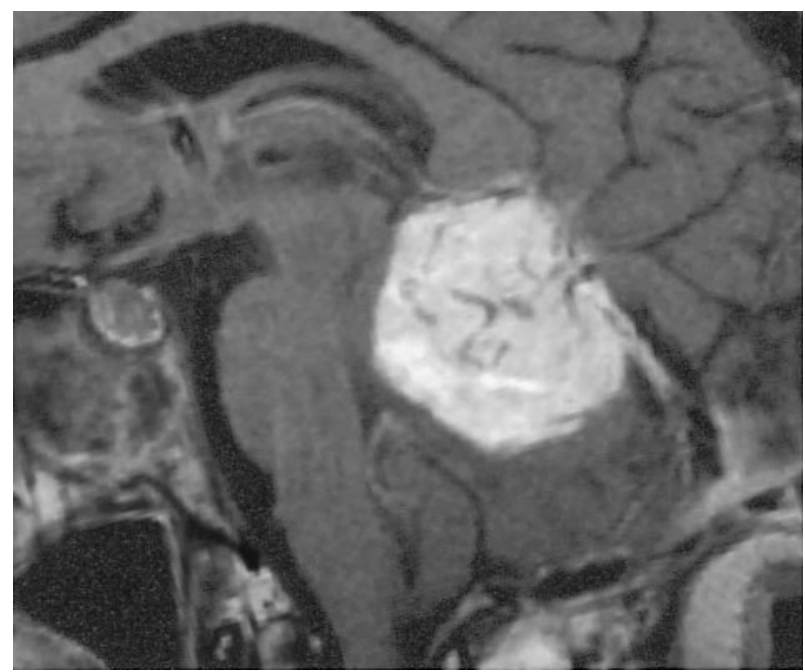

Fig. 7. A large solid recurrent HB 11 years after the primary total removal in a 66-year-old non-VHL patient

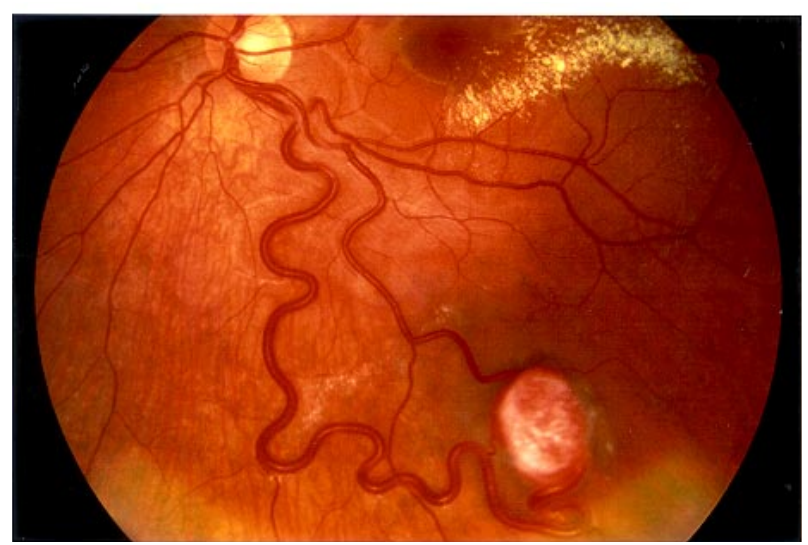

Fig. 8. Ophthalmoscopic view before treatment of a typical retinal HB with draining vessels

as their first VHL manifestation. Four patients had visual disturbances, and four were asymptomatic at detection. When a patient had HBs both of the CNS and the retina, there were always other VHL manifestations present.

\section{Cysts of Internal Organs}

In 11 of the $14 \mathrm{VHL}$ patients, the upper abdomen was studied by CT, ultrasound, surgery or autopsy, and cysts were found in eight patients. None of the cysts were the sole indication for surgical intervention. There were 13 patients with a single HB and asymptomatic cyst(s) of internal organs. The median age of 56 years at the first HB operation, the lack of other VHL- associated manifestations, negative family history, and no germ-line mutations of the VHL gene (11 patients studied) together suggest that the internal organ cyst(s) in these 13 patients were incidental findings. The cyst(s) occurred in the kidney(s) in 10 patients (three bilateral), in the liver in four patients, in the pancreas in two patients, and in the spleen in one patient. The abdominal organs of 60 patients, regarded to be free of VHL, were imaged by CT (54 patients) or ultra sound (six patients), and incidental cysts were found in $17 \%$ $(10 / 60)$ in the kidneys, $7 \%$ in the liver $(4 / 60)$, and $3 \%$ $(2 / 60)$ in the pancreas.

\section{Long-Term Survival of VHL and Non-VHL Patients}

A total of 12 of the $14 \mathrm{VHL}$ patients survived at least two years after the primary HB operation. The median follow-up time for these 12 patients was 16 (4-26) years, and during the follow-up nine of them died at a median age of 47 (26-66) years. All died of the disease, five of RCC at a median of 49 (26-66) years, three of $\mathrm{HB}(\mathrm{s})$ at a median age of 47 (46-51) years, and one of pancreatic carcinoma at 45 years.

A total of 70 of the 96 non-VHL patients survived more than two years after the primary radical HB removal. During the median follow-up time of 16 years (range 2-36 years), 18 patients died at the median age of 65 years (range $51-81$ years). There were six deaths due to recurrence of the $\mathrm{HB}$ at the original operation site after a median of 15 years (range 3-35 years) at the median age of 66 years (range 55-81), and 12 nonrelated deaths at the median of 65 years (range 51-77).

\section{Discussion}

\section{The Prevalence of VHL in HB Patients}

The prevalence of VHL is at least $13 \%$ in this unselected and population-based series of 110 patients operated on for HBs of the CNS, which appears to be an underestimation when compared to recent studies $[1,27,34,39,41]$, showing prevalence of up to $40 \%$. Our series was retrospective spanning over four decades, and characterized by high operative mortality in the early years. On the other hand, the follow-up time was long and all available data were collected to detect the cases of VHL: 61 live patients were studied clinically in detail, eight patients had clearly developed VHL, in 17 patients autopsy excluded VHL, and 12 patients reached the age of 65 years or more without 
signs of VHL. This left 13 patients with data insufficient to rule out VHL.

\section{Detection of VHL Manifestations}

All patients with $\mathrm{HB}(\mathrm{s})$ of the CNS should be screened for VHL by MRI of the brain and spinal cord, ophthalmoscopy, abdominal CT or MRI, and by obtaining the family history. Early detection of incidental $\mathrm{HB}(\mathrm{s})$ of the CNS may be more favourable at least in terms of radiosurgery $[6,37]$. When retinal HBs are small and asymptomatic they are easier to treat with laser or cryocoagulation, and the prognosis of vision is better [52]. The prognosis of RCC is probably also better with early detection [15, 36, 45]. In our series, VHL-related $\mathrm{HB}(\mathrm{s})$ were detected at a median age of 33 years, in accordance with earlier studies [35, 39]. Retinal HBs were diagnosed at the median age of 39 years in contrast to the 25 years in VHL-based series [35, 51]. RCC was detected at a median age of 43 years, somewhat later than the 33 years in a recent series [35].

\section{Lesions Suggestive of VHL}

The lesions detected in VHL may also occur incidentally in otherwise healthy subjects, but typically at an older age than in VHL patients [35, 39]. Multiple HBs of the CNS are considered as a classical sign of VHL. In our series, one non-VHL patient (1\%) had two HB nodules in the same cyst wall at the primary removal. Negative family history and no germ-line mutation found together with the lack of other VHL manifestations during the long follow-up suggest that this patient did not have VHL. Multiple HBs may still represent mosaicism or segmental VHL, negative family history explained by mosaicistic or no VHL gene defect in the germ cells. Neurofibromatosis type 2 (NF2), another dominantly inherited syndrome with a defective NF2 tumour suppressive gene predisposes to multiple schwannomas and meningiomas, but the defective NF2 gene is also causative of sporadic schwannomas and meningiomas [13, 19, 29, 43, 44]. In the schwannoma population, $95 \%$ are single and obviously sporadic, $2 \%$ are multiple but without classical NF2, and 3\% are related to NF2 (Antinheimo J, unpublished population-based study).

VHL patients have HBs in the brain stem and spinal cord more often than non-VHL patients [14, 20, 27, 39,41 , which was also confirmed by our study. Brain stem and spinal cord locations contribute to the increased management morbidity of HBs in VHL. Visceral cysts in patients with a single $\mathrm{HB}$ of the CNS may suggest VHL. In our series, however, 13 (14\%) HB patients who were considered as free of VHL had visceral cysts. Characteristically they had less cysts per organ and patient than the VHL patients. The occurrence of non-VHL cysts in our series corresponds to that of the general population $[5,18,23,48]$.

\section{Mutation Analysis}

In our series, six of the 14 VHL patients had a family history $(43 \%)$ for the disease, and eight patients had apparently a new mutation, a proportion corresponding to the literature [25]. We used direct sequencing of the VHL gene which is more sensitive than SSCP (Single Strand Conformation Polymorphism) that detects $50 \%$ of VHL mutations $[7,22,53]$. We found a germ-line mutation in exon 1 in two of the four VHL patients studied (Case 8: $278 \mathrm{G}$ to C; Case 11: $293 \mathrm{~A}$ to G). Both mutations cause an amino-acid missense substitution (Gly - Ala and Tyr - Cys, respectively), and are known to be associated with pheochromocytomas which appeared in the family of one VHL patient [8]. Recent data suggest that with combined techniques (Southern blotting, fluorescence in situ hybridisation, and sequencing of the gene) virtually all mutation carriers could be identified [46]. The children of a patient with a VHL gene defect have a risk of $50 \%$ of getting the disease, and they should be offered the possibility of predictive germ-line mutation testing to avoid laborious and expensive long-term clinical screening. It is not possible to predict reliably the severity and spectrum of VHL manifestations based on any single VHL gene defect $[8,11,35,51]$.

\section{Recurrence of Haemangioblastomas}

HB is a slowly growing tumour. There is a general impression that VHL-associated HBs would grow faster than sporadic HBs, but this is difficult to prove because no volume growth data are available for nonVHL tumours. Time to recurrence in the original operation area after seemingly complete removal tells something about the volume growth rate but de novo tumours may be mistaken for recurrences in VHL patients. Our series suggests that VHL and non-VHL HBs grow similarly because the median times to recurrence were 19 years and 11 years, respectively, and 
the median MIB indices of $0.3 \%$ and $0.2 \%$, respectively, suggest similar low growth potential. In a series of $27 \mathrm{HBs}$, without distinction of VHL tumours, the mean MIB-1 index was 2.8\%, higher than in our series, possibly due to differences in staining and quantitation protocols [2]. HB is a microsurgically curable tumour but the risk of late recurrences may be higher than generally expected. In a previous series of $26 \mathrm{HB}$ patients operated on between 1974 and 1986, seven patients developed a recurrence at a mean interval of seven years after total removal [12]. Recurrences at the original operation site were detected in 13 of our 84 patients after seemingly complete removal, performed between 1953 and 1993, and the median time to recurrence was considerably longer, 16 years. Also, seven died of recurrence at a median of 20 years (3-35) after the primary complete removal. Late recurrences are a challenge in terms of detection and microsurgery in the elderly.

\section{Long-Term Survival of VHL Patients}

The average life-expectancy of VHL patients is 40 to 50 years [31], 46 years in our series. At present RCC is the leading cause of death of VHL patients [26], and it was also a major cause of mortality in our series. In a recent series of $65 \mathrm{VHL}$ patients with RCC treated by radical nephrectomy or nephron-sparing surgery, the RCC specific survival rate at five and 10 years was 95 and $77 \%$, respectively, but $23 \%$ of the patients developed end-stage renal failure [45]. Renal transplantation is an option to treat anephric VHL patients. A series of 28 patients suggested that immunosuppression would not enhance the growth of existing tumours [15]. Further studies with long follow-up are needed to show whether prolonged immunosuppression increases the risk of second malignancies in VHL patients with renal transplants [38]. These aspects are crucial when deciding whether prophylactic bilateral nephrectomy with renal transplantation is offered as a life-saving treatment for VHL patients. Another way to go would be to develop a specific drug therapy against HBs and RCCs, e.g., relating to angiogenesis in both tumours.

\section{Conclusions}

1. The frequency of VHL in patients operated on for $\mathrm{HB}(\mathrm{s})$ of the CNS was $31 \%$ before the age of 25 years, $19 \%$ between 25 and 45 years, and only $2 \%$ thereafter.
2. In the VHL patients, $\mathrm{HB}(\mathrm{s})$ of the CNS were detected at the median age of 33 years, followed by retinal HBs at 39 years, and RCC at 43 years.

3. Half of the VHL patients had spinal and/or brain stem HBs at some stage in comparison to only 4 $5 \%$ of non-VHL patients.

4. One non-VHL patient had two adjacent HBs in the same cyst wall.

5. Internal organ cysts in HB patients do not necessarily indicate VHL.

6. The growth rates of non-VHL and VHL-related HBs were similar as indicated by the median time to recurrence and the MIB-indices.

7. HB recurrence developed in four of the $10 \mathrm{VHL}$ patients whose primary surgery was considered to be radical after a median of 19 years, and in nine of the 74 non-VHL patients after a median of 11 years.

8. The median length of life of VHL patients was 46 years, with RCC and HBs as equal causes of death.

\section{References}

1. Boughey AM, Fletcher NA, Harding AE (1990) Central nervous system hemangioblastoma: a clinical and genetic study of 52 cases. J Neurol Neurosurg Psychiatry 53: 644-648

2. Brown DF, Gazdar AF, White CL, Yashima K, Shay JW, Rushing EJ (1997) Human telomerase RNA expression and MIB-1 (Ki-67) proliferation index distinguish hemangioblastomas from metastatic renal cell carcinomas. J Neuropath Exp Neurol 56: 1349-1355

3. Böhling T, Haltia M, Rosenlöf K, Fyhrquist F (1987) Erythropoietin in capillary hemangioblastoma. An immunohistochemical study. Acta Neuropathol 74: 324-328

4. Böhling T, Hatva E, Plate K, Haltia M, Alitalo K (1997) von Hippel-Lindau disease and capillary hemangioblastoma. In: Kleihues P, Cawenee W (eds) Pathology and genetics of tumours of the nervous system. WHO International Agency for Research on Cancer, Lyon, pp 179-181

5. Caremani M, Vincenti A, Benci A, Sassoli S, Tacconi D (1996) Echographic epidemiology of non-parasitic hepatic cysts. J Clin Ultrasound 21: 115-118

6. Chang SD, Meisel JA, Hancock SL, Martin DP, McManus M, Adler JR (1998) Treatment of hemangioblastomas in von Hippel-Lindau disease with linear accelerator-based radiosurgery. Neurosurgery 43: 28-35

7. Chen F, Kishida T, Yao M, Hustad T, Glavae D, Dean M, Gnarra JR, Orcutt ML, Duh FM, Glenn G, Green J, Hsia YE, Lamiell J, Li H, Schmidt L, Tory K, Kuzmin I, Stackhouse T, Latif F, Linehan WM, Lerman M, Zbar B (1995) Germline mutations in the von Hippel-Lindau disease tumor suppressor gene: correlations with phenotype. Hum Mutat 5: 66-75

8. Chen F, Slife L, Kishida T, Mulvihill J, Tisherman SE, Zbar B (1996) Genotype-phenotype correlation in von Hippel-Lindau disease: identification of a mutation associated with VHL type 2A. J Med Genet 33: 716-717

9. Choyke P, Glenn G, Walther M, Patrona N, Linehan W, Zbar B (1995) von Hippel-Lindau disease: genetic, clinical, and imaging features. Radiology 194: 629-642 
10. Choyke PL, Glenn GM, Walther MM, Zbar B, Weiss GH, Alexander RB, Hayes WS, Long JP, Thakore KN, Linehan WM (1992) The natural history of renal lesions in von HippelLindau disease: a serial CT study in 28 patients. AJR 159: 12291234

11. Crossey PA, Richards FM, Foster K, Green JS, Prowse A, Latif F, Lerman MI, Zbar B, Affara NA, Ferguson-Smith MA, Maher ER (1994) Identification of intragenic mutations in the von Hippel-Lindau disease tumour suppressor gene and correlation with disease phenotype. Hum Mol Gen 3: 1303-1308

12. de la Monte SM, Horowitz SA (1989) Hemangioblastomas: clinical and histopathological factors correlated with recurrence. Neurosurgery 25: 695-698

13. Fearon ER (1997) Human cancer syndromes: clues to the origin and nature of cancer. Science 278: 1043-1050

14. Filling-Katz MR, Choyke PL, Oldfield E, Charnas L, Patronas NJ, Glenn GM, Gorin MB, Morgan JK, Linehan WM, Seizinger BR, Zbar B (1991) Central nervous system involvement in von Hippel-Lindau disease. Neurol 41: 41-46

15. Goldfarb DA (1998) Nephron-sparing surgery and renal transplantation in patients with renal cell carcinoma and von HippelLindau disease. J Int Med 243: 563-567

16. Grossniklaus HE, Thomas JW, Vigneswaran N, Jarrett WH (1992) Retinal hemangioblastoma. A histologic, immunohistochemical, and ultrastructural evaluation. Ophthalmol 99: $140-145$

17. Haapasalo H, Isola J, Sallinen P, Kalimo H, Helin H, Rantala I (1993) Aberrant p53 expression in astrocytic neoplasms of the brain: association with proliferation. Am J Pathol 142: 13471351

18. Howard JM (1989) Cystic neoplasms and true cysts of the pancreas. Surg Clin North Am 69: 651-665

19. Jacoby LB, Jones D, Davis K, Kronn D, Short MP, Gusella J, MacCollin M (1997) Molecular analysis of the NF2 tumorsuppressor gene in schwannomatosis. Am J Hum Genet 61: $1293-1302$

20. Julow J, Balint K, Gortvai P, Pasztor E (1994) Posterior fossa hemangioblastomas. Acta Neurochir (Wien) 128: 109-114

21. Lamiell JM, Salazar FG, Hsia YE (1989): von Hippel-Lindau disease affecting 43 members of a single kindred. Medicine 68: $1-29$

22. Latif F, Tory K, Gnarra J, Yao M, Duh FM, Orcutt M, Stackhouse T, Kuzmin I, Modi W, Geil L, Schmidt L, Zhou F, Li H, Wei M, Chen F, Glenn G, Choyke P, Walther Mc C, Weng Y, Duan D-SR, Dean M, Glavac P, Richards F, Grosssey P, Ferguson-Smith M, LePaslier D, Chumakov I, Cohen D, Chinault C, Maher E, Linehan W, Zbar B, Lerman M (1993) Identification of the von Hippel-Lindau disease tumor suppressor gene. Science 260: 1317-1320

23. Laucks SP, McLachlan MS (1981) Aging and simple cysts of the kidney. Br J Rad 54: 12-14

24. Lindau A (1926) Studien über Kleinhirncysten. Bau, Pathogenese in Beziehungen zur Angiomatosis retinae. Acta Pathol Microbiol Scand [Suppl] 1: 1-128

25. Maher ER, Iselius L, Yates JR, Litteler M, Benjamin C, Harris R, Sampson J, Williams A, Ferguson-Smith MA, Morton N (1991) Von Hippel-Lindau disease: a genetic study. J Med Genet 28: 443-447

26. Maher ER, Kaelin WG Jr ( 1997) von Hippel-Lindau disease. Medicine 76: 381-391

27. Maher ER, Yates JR, Ferguson-Smith MA (1990) Statistical analysis of the two stage mutation model in von Hippel-Lindau disease, and in sporadic cerebellar hemangioblastoma and renal cell carcinoma. J Med Genet 27: 311-314
28. Maher ER, Yates JR, Harries R, Benjamin C, Harris R, Moore AT, Ferguson-Smith MA (1990) Clinical features and natural history of von Hippel-Lindau disease. Q J Med 77: 1151-1163

29. MacCollin M, Woodfin W, Kronn D, Short MP (1996) Schwannomatosis: a clinical and pathologic study. Neurol 46: 1072-1079

30. Melmon K, Rosen S (1964) Lindau's disease. Review of the literature and study of a large kindred. Am J Med 36: 595-617

31. Neumann HP (1987) Prognosis of von Hippel-Lindau syndrome. VASA 16: 309-311

32. Neumann HP, Bender BV, Berger DP, Laubenberger J, Schultze-Seemann W, Wetterauer U, Ferstl FJ, Herbst EW, Schwarzkopf G, Hes FJ, Lips CJ, Lamiell JM, Masek O, Rigel P, Mueller B, Glavac P, Brauch H (1998) Prevalence, morphology and biology of renal cell carcinoma in von HippelLindau disease compared to sporadic renal cell carcinoma. J Urol 160: 1248-1254

33. Neumann HP, Berger DP, Sigmund G, Blum U, Schmidt D, Parmer RJ, Volk B, Kirste G (1993) Pheochromocytomas, multiple endocrine neoplasia type 2 and von Hippel-Lindau disease. N Engl J Med 329: 1531-1538

34. Neumann HP, Eggert HR, Weigel K, Friedburg H, Wiestler OD, Schollmeyer P (1989) Haemangioblastomas of the central nervous system. J Neurosurg 70: 24-30

35. Neumann HP, Lips CJ, Hsia YE, Zbar B (1995) von HippelLindau syndrome. Brain Pathology 5: 181-193

36. Neumann HP, Zbar B (1997) Renal cysts, renal cancer and von Hippel-Lindau disease. Kidney Int 51: 16-26

37. Niemelä M, Lim YJ, Söderman M, Jääskeläinen J, Lindquist C (1996) Gamma knife radiosurgery in 11 hemangioblastomas. J Neurosurg 85: 591-596

38. Penn I (1993) The effect of immunosuppression on pre-existing cancers. Transplantation 55: 742-747

39. Resche F, Moisan JP, Mantoura J, de Kersaint-Gilly A, Andre M, Perrin-Resche I, Menegalli-Boggelli D, Lajat Y, Richard S (1993) Haemangioblastoma, haemangioblastomatosis, and von Hippel-Lindau disease. In: Symon L et al (eds) Advances and technical standards in neurosurgery, vol 20. Springer, Wien New York, pp 197-303

40. Richard S, Beigelmann C, Gerber S, van Effenterre R, Gaudric A, Sahel M, Binaghi M, de Kersaint-Gilly A, Houtteville J, Brunon JP (1994) L'hemangioblastome existe-t-il en dehors de la maladie de von Hippel-Lindau? Neurochirurgie 40: 145154

41. Richard S, Campello C, Taillandier L, Parker F, Resche F (1998) Hemangioblastoma of the central nervous system in von Hippel-Lindau disease. J Int Med 243: 547-553

42. Sallinen P, Haapasalo H, Kerttula T, Rantala I, Kalimo H, Collan Y, Isola J, Helin H (1994) Sources of variation in the assessment of cell proliferation using proliferating cell nuclear antigen immunohistochemistry. Anal Quant Cytol Histol 16: 261-268

43. Seppälä MT, Haltia MJ, Sankila RJ, Jääskeläinen JE, Heiskanen O (1995) Long-term outcome after removal of spinal schwannoma: a clinicopathological study of 187 cases. J Neurosurg 83: 621-626

44. Seppälä MT, Sainio MA, Haltia MJ, Kinnunen JJ, Setälä KH, Jääskeläinen JE (1998) Multiple schwannomas: schwannomatosis or niurofibromatosis type 2? J Neurosurg 89: 36-41

45. Steinbach F, Novick AC, Zincke H, Miller DP, Williams RD, Lund G, Skinner DG, Esrig D, Richie JP, deKernion JB, Marshall F, Marsh CL (1995) Treatment of renal cell carcinoma in von Hippel-Lindau disease: a multicentre study. J Urol 153: $1812-1816$ 
46. Stolle C, Glenn G, Zbar B, Humphrey JS, Choyke P, McClellan W, Pack S, Hurley K, Andrey C, Klausner R, Linehan WM (1998) Improved detection of germline mutations in the von Hippel-Lindau disease tumor suppressor gene. Hum Mutat 12: 417-423

47. Teppo L, Pukkala E, Lehtonen M (1994) Data quality and quality control of a population-based cancer registry. Experience in Finland. Acta Oncol 33: 365-369

48. Tsugaya M, Kajita A, Hayashi Y, Okamura T, Kohri K, Kato Y (1995) Detection and monitoring of simple renal cysts with computed tomography. Urol Intern 54: 128-131

49. von Hippel E (1911) Die anatomische Grundlage der von mir beschriebenen "sehr seltene Erkrankung der Netzhaut". A von Graefe's Arch Ophthalmol 79: 350-377

50. Webster AR, Maher ER, Bird AC, Gregor ZJ, Moore AT (1999) A clinical and molecular genetic analysis of solitary ocular angioma. Ophthalmology 106: 623-629

51. Webster AR, Maher ER, Moore AT (1999) Clinical characteristics of ocular angiomatosis in von Hippel-Lindau disease and correlation with germline mutation. Arch Ophthalmol 117: 371378

52. Wittebol-Post D, Hes FJ, Lips CJ (1998) The eye in von HippelLindau disease. Long-term follow-up of screening and treatment. Recommendations. J Int Med 243: 555-561

53. Zbar B, Kishida T, Chen F, Schmidt L, Maher ER, Richards FM, Crossey PA, Webster AR, Affara NA, Ferguson-Smith MA, Brauch H, Glavac D, Neumann HP, Tisherman S, Mulvihill JJ, Gross DJ, Shuin T, Whaley J, Seizinger B, Kley N,
Olscwang S, Boisson C, Richards S, Lips CH, Linehan WM, Lerman M (1996) Germline mutations in the von Hippel-Lindau disease (VHL) gene in families from North America, Europe and Japan. Hum Mut 8: 348-357

\section{Comments}

This is an excellent overview on haemangioblastomas of the CNS. No patient was lost to follow up. Therefore, I would highly recommend this paper for publication. It is a valuable source of information for physicians who have to treat and councel patients with haemangioblastomas.

The emphasis on tumours of the abdomen associated with VHLDisease is particularly important. Life expectancy of patients with VHL-Disease was limited by these tumours rather than the CNS tumour. Therefore, it is important to examine each patient with a haemangioblastoma for evidence of VHL-Disease. I found it interesting to note that haemangioblastomas of the brain stem and spinal cord were much more common in VHL-Disease. The higher rate of tumour recurrence in patients with VHL was also found in our material.

M. Samii-J. Klekamp

Correspondence: Mika Niemelä, M.D., Department of Neurosurgery, Helsinki University Hospital, Topeliuksenkatu 5, 00260 Helsinki, Finland. 